Canadian

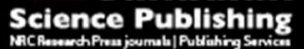

Canadian Journal of Civil Engineering Revue canadienne de génie civil

\title{
SOIL AQUIFER TREATMENT OF SECONDARY EFFLUENTS AND COMBINED SEWER OVERFLOWS IN HIGHLY PERMEABLE SOILS TYPICAL OF SOUTHWESTERN ONTARIO
}

\begin{tabular}{|r|l|}
\hline Journal: & Canadian Journal of Civil Engineering \\
\hline Manuscript ID & cjce-2016-0306.R2 \\
\hline Manuscript Type: & Article \\
\hline Date Submitted by the Author: & $17-$ Dec-2016 \\
\hline Complete List of Authors: & $\begin{array}{l}\text { Velasquez, Diego; The University of Western Ontario, Civil and } \\
\text { Environmental Engineering } \\
\text { Yanful, Ernest K.; Western University, Department of Civil and } \\
\text { Environmental Engineering } \\
\text { Sun, Weijian; The University of Western Ontario, Civil and Environmental } \\
\text { Engineering }\end{array}$ \\
\hline Keyword: & $\begin{array}{l}\text { environmental < MANUSCRIPT CLASSIFICATION, wastewater treat \& disp } \\
\text { sustainability, wastewater reclamation }\end{array}$ \\
\hline
\end{tabular}




\title{
SOIL AQUIFER TREATMENT OF SECONDARY EFFLUENTS AND COMBINED SEWER OVERFLOWS IN
} HIGHLY PERMEABLE SOILS TYPICAL OF SOUTHWESTERN ONTARIO

\author{
D. Velasquez, E.K. Yanful and W. Sun \\ Department of Civil and Environmental Engineering \\ Western University, 1151 Richmond Street, London, Ontario, Canada N6A 5B9
}

Corresponding author e-mail: dvelasqu@uwo.ca 
Abstract:

Wastewater reclamation is becoming an important alternative for sustainable water resources management and building climate change resiliency in many regions around the world. This research investigated the polishing of secondary effluents and Combine Sewer Overflows (CSOs) by a laboratory scale Soil Aquifer Treatment (SAT) considering local soils and wastewater characteristics of southwestern Ontario. Results show that high permeability soils of southwestern Ontario, have the ability to polish secondary effluents in terms of DOC, E. coli and total coliforms. Regarding the simulated CSOs, low to moderate improvements of wastewater quality were observed. Denitrification of secondary effluents improved significantly by the addition of readily available organic matter, which supports the importance of protecting recharge wetlands for groundwater quality protection. SAT in southwestern Ontario is a feasible alternative for the recharge of non-potable and potable aquifers with secondary effluents. However, for potable aquifers further treatment of wastewater effluents may be required.

Key words: Soil Aquifer Treatment, resiliency, water resources management, wastewater reclamation, sustainability. 


\section{INTRODUCTION}

Water resources around the world are under increasing pressure from the rapidly growing demands of rising population and industrialization. Furthermore, changes in global weather patterns are expected to intensify its current and future stresses. Searching for alternative sources of water such as the recovery of rain water, desalination of seawater or brackish groundwater, on-site grey water reuse and the reclamation of municipal waste are important approaches to reducing the pressure on fresh water availability (NRC 2012). Reclamation of wastewater effluents is the process of treating wastewater to high quality standards to make it suitable for potable or non-potable applications.

Reclamation of highly treated wastewater has become a feasible alternative for augmenting drinking water supplies, such as groundwater and surface waters, largely because of advances in treatment technology that enables the production of high quality recycled water at increasingly reasonable costs and reduced energy inputs (Rodriguez et al. 2009). Additionally, public confidence in water reclamation projects is higher when the reclaimed water is put back into natural systems prior to be reused (Haddad et al. 2009; Dillon et al. 2006).

Advantages of aquifer storage over surface water reservoirs includes a higher capacity of storage, lower requirements for land, lower costs, prevents evaporation losses and, by recharging through unsaturated soil layers, it provides additional purification to the treated effluent (Dillon et al. 2006; Wintgens et al. 2008; Bdur et al. 2009). Groundwater recharge can be achieved by the direct injection of treated wastewater into the aquifer or by allowing the treated wastewater to infiltrate and percolate through the soil into the aquifer. The latter is also known as Soil-Aquifer Treatment (SAT). SAT involves the infiltration of the wastewater effluent through a recharge basin followed by the recovery of the purified wastewater through recovery wells.

Several field and laboratory-scale studies have been carried out around the world to determine the effectiveness of SAT at removing specific pollutants from treated wastewater effluents (Fox 2001; Cha et al. 2005; Drewes et al. 1999; Essandoh et al. 2013; Essandoh et al. 2011; Fox et al. 2005; Harun 2007; NCSWS 2001; 
Quanrud et al. 2003; Sharma et al. 2008). SAT for CSOs has not been as extensively investigated as secondary and tertiary effluents. Combined systems carry sanitary and storms sewer simultaneously to the wastewater treatment plant to be treated. However, during storm events, the volume of stormwater collected by the combined sewer systems may exceed the treatment capacity of the wastewater plant, resulting in the release of untreated sewage into the local water ways. These CSO discharges are considered a significant source of pollution in the Great Lakes. An estimated 92 billion litres of CSOs are released into the Great Lakes in one year by cities in the Great Lakes basin (Ecojustice 2013).

The performance of SAT systems is affected by the quality of influent wastewater, the specific characteristics of the site (climate, geology and hydrogeology) and the operational schedule of the infiltration basins. Water quality concerns of wastewater reclamation subjected to SAT include organics, nitrogen species, heavy metals, pathogens and emergent contaminants such as pharmaceuticals (Dolnicar and Schafer 2009; US-EPA 2011).

Centralized wastewater reuse in Canada is limited to agricultural irrigation, and golf course and urban landscape irrigation, and there are no regulations for indirect potable reuse (Exall et al. 2006) such as aquifer recharge. Some guidelines for municipal wastewater reclamation have been developed at the federal level and by the provinces of British Columbia, Alberta, Saskatchewan, Manitoba and Prince Edward Island (CMHC 2005). Federal guidelines have been developed specific to the use of reclaimed domestic wastewater for toilet and urinal flushing (GC 2011). British Columbia is the province with the most comprehensive guidelines, but they are limited to urban and agricultural irrigation (CMHC 2005).

The purpose of this research was to investigate the prospect of SAT of secondary effluents and CSOs for indirect potable or non-potable reuse by using a laboratory scale SAT system. The SAT system was built taking into consideration the subsurface geology of southwestern Ontario and operated with wastewater collected from a local wastewater treatment plant. 


\section{STUDY SITE}

Southwestern Ontario is a region in south Ontario, with a population of approximately 3.5 million. It extends from the City of Windsor to the City of Guelph and it is bound by Lake Huron to the north, Lake Erie to the south and Lake St Clair to the west. Sources of drinking water in southwestern Ontario include the Great Lakes (Lake Erie and Lake Huron) and groundwater. For instance, the City of London, which is the largest city in southwestern Ontario with a population of 366,151 (2011 census), relies of Lake Huron and Lake Erie as drinking water sources. Additionally, a network of 7 groundwater wells is maintained as back up for emergency situations (City of London 2014; UTRCA 2011). Moreover, the Regional Municipality of Waterloo, also part of Southwestern Ontario, with a combined population of 507,100 (2011 census) relies on buried, "semi-confined" aquifers for drinking water (Region of Waterloo 2010).

The current surficial deposits and landscape of southwestern Ontario are the result of the last glaciation, known as the Wisconsin glacial events, leaving behind sediments such as tills, glaciofluvial sand and gravel, glaciolacustrine and glaciomarine silts and clays (Chapman and Putnam 1984; OGS 2010). The Ontario Geological Survey (2010) classified the sediments in Ontario with ranking of high, medium and low permeability based on the characteristics of material types. According to this classification, $29 \%, 65 \%$ and $6 \%$ of the sediments of southwestern Ontario have high, low and variable permeability respectively. See Figure 1 . High permeability soils are preferable over low permeability for surface infiltration systems to maintain high infiltration rates and minimize land requirements (Bouwer 2002). Additionally, when high permeability soils in southwestern Ontario are classified according to material description, fine to medium grained sands are the most prevalent (OGS 2010). The Udden-Wentworth grain size classification scheme (Wentworth 1922) defines fine grain size between 0.125 to $0.25 \mathrm{~mm}$ and medium grain size between 0.25 and $0.50 \mathrm{~mm}$. The coefficient of permeability $(\mathrm{K})$ for fine to medium grain size soils varies approximately between 1 to $20 \mathrm{~m} / \mathrm{d}$ (Bouwer 1978). Figures 2 shows high permeability soils of southwestern Ontario classified by primary material (OGS 2010). 


\section{MATERIALS AND METHODS}

A laboratory scale SAT system was constructed and packed with fine to medium natural sand collected from the banks of the Medway Creek (MC), a tributary of the Thames River in London, ON. The SAT system was built using a polyvinyl chloride (PVC) column with an internal diameter of $5 \mathrm{~cm}$ and effective length of $90 \mathrm{~cm}$. A series of sampling ports that extended from the center of the column's cross section were installed at multiple depths from the soil surface at $0,10,30,50,70,90 \mathrm{~cm}$. The SAT system was operated under gravity flow conditions at a constant head of $20 \mathrm{~cm}$, which was maintained by the use of a top feeding tank with an overflow weir, a peristaltic pump and flexible PVC tubing. Additionally, a valve was installed at the outlet to be able to control the outlet flow and, therefore, hydraulic retention times (HRTs). Figure 3 shows a schematic representation of the experimental set up.

The collected MC sand was washed, dried for 72 hours at $65{ }^{\circ} \mathrm{C}$ and sieved before packing the column to a typical dry bulk density of sandy soils of $1.52 \mathrm{~g} / \mathrm{cm}^{3}$. The bottom $20 \mathrm{~cm}$ of the column were filled with gravel to support the sand. Graphic geometric mean and standard deviation of the sieved MC sand were measure in phi units $(\Phi)$ as $1.9 \Phi$ and $0.55 \Phi$ (moderately well sorted) respectively. Specific gravity was measured using a Pycnometer as 2.65. Additionally, major oxides composition (wt\%) and trace elements $(\mathrm{ppm})$ in the sand were determined by Fusion X-Ray Fluorescence (XRF) and pressed pellet XRF respectively (table 1). Average total organic carbon content was measured as $3 \%(n=4)$ by TOC analyzer. Porosity and total pore volume were calculated as $42 \%$ and $831 \mathrm{~cm}^{3}$ respectively.

The laboratory scale SAT system was operated with secondary effluents and CSOs for a period of 12 consecutive months on cycles of 7 days wetting and 7 days drying at $20^{\circ} \mathrm{C}\left( \pm 1^{\circ} \mathrm{C}\right)$ at $3 \mathrm{HRTs}$ representative of high permeability soils. After a wetting cycle of several days, a drying cycle is usually necessary to restore surface permeability and increase the column redox potential (Bouwer 2002). Simulated CSOs were prepared in the laboratory by diluting raw wastewater with distilled water at a ratio of 1:2 (Gandhi et al. 2014). 
Denitrification enhancement was also investigated by the addition of readily available organic carbon (methanol and glucose). Methanol has been commonly employed as external carbon source due to being easily assimilated by denitrifying bacteria and its low cost (Peng et al. 2007; Fernández-Nava et al. 2010). Stoichiometry indicates that for each gram of nitrate-nitrogen that is reduced, 1.9 grams of methanol are needed. However, in practice, methanol to $\mathrm{NO}_{3}^{-}-\mathrm{N}$ dose ratios are in the range of 2 to $3.5 \mathrm{~g}$ methanol/ $\mathrm{g} \mathrm{NO}{ }_{3}^{-}-\mathrm{N}$ at $20^{\circ} \mathrm{C}$ (EPA 1970; Tchobanoglous et al. 2003). Glucose has the potential of sustainably enhancing denitrification and, unlike methanol, it is nonhazardous. Stoichiometry indicates that for each gram of nitrate-nitrogen that is reduced, 2.68 grams of glucose are needed. In practice, a $\mathrm{C} / \mathrm{N}$ ratio of 5:1 for complete denitrification has been reported (Naik and Setty 2012). Readily available organic matter was added to the secondary effluents at methanol/glucose: nitrogen ratios of $1: 1,3: 1$ and $6: 1$ and operated at a HRT of 2.8 hours. A summary of the experiments performed during the SAT system operation is presented in table 2.

Secondary effluent and raw wastewater were both collected from the Adelaide Pollution Control Plant (APCP) in London, Ontario, and stored at $4{ }^{\circ} \mathrm{C}$ in 5 gallons high density polyethylene drums. Since the column was operated at $20^{\circ} \mathrm{C}\left( \pm 1^{\circ} \mathrm{C}\right)$, stored wastewater was allowed to acclimatize to the column operating conditions before introducing it into the system. The APCP provides secondary level treatment to domestic and industrial wastewater by the activated sludge process and discharges its treated effluent to the Thames River, a tributary of the Great Lakes. The activated sludge process at the APCP is designed to provide both $\mathrm{BOD}_{5}$ removal and nitrification. Phosphorous removal is achieved by the addition of cationic polymers and iron salts and disinfection, between April 1 and September 30, by ultraviolet light (City of London 2014). Effluent limits for monthly averages set by Ontario Ministry of the Environment Certificate of Approval No. 7397-96SPH7 for the APCP are $10 \mathrm{mg} / \mathrm{L}$ for $\mathrm{CBOD}_{5}$ and Total Suspended Solids, $1 \mathrm{mg} / \mathrm{L}$ for Total Phosphorus, $0.1 \mathrm{mg} / \mathrm{L}$ for unionized ammonia and $200 \mathrm{CFU} / 100 \mathrm{ml}$ (geometric mean) for Escherichia coli (E.coli) during disinfection season (MOE 2013). In 2014, average $\mathrm{BOD}_{5}$, suspended solids, total phosphorus, free $\mathrm{NH}_{3}-\mathrm{N}$, total Kjeldahl nitrogen and 
$\mathrm{NO}_{3}{ }^{-}-\mathrm{N}$ for the secondary effluents at APCP were $3 \mathrm{mg} / \mathrm{L}, 3 \mathrm{mg} / \mathrm{L}, 0.58 \mathrm{mg} / \mathrm{L}, 0.4 \mathrm{mg} / \mathrm{L}, 2 \mathrm{mg} / \mathrm{L}$ and $16.4 \mathrm{mg} / \mathrm{L}$ respectively (City of London 2015).

Samples were collected on the last day of the wetting cycle, filtered with a $0.45 \mu \mathrm{m}$ membrane filter when necessary and stored at $4^{\circ} \mathrm{C}$ prior to analysis. Secondary effluents utilized for experiments $\mathrm{A}, \mathrm{B}$ and $\mathrm{C}$ were analyzed for dissolved oxygen (DO), Dissolved Organic Carbon (DOC), E. coli, total coliforms, ammonia $\left(\mathrm{NH}_{3}\right)$, phosphate ions $\left(\mathrm{PO}_{4}{ }^{3-}\right)$, nitrate ions $\left(\mathrm{NO}_{3}{ }^{-}\right)$and sulphate ions $\left(\mathrm{SO}_{4}{ }^{2-}\right)$ at all column depths. Simulated $\mathrm{CSO}$ used for experiment $\mathrm{D}$ were analyzed for $\mathrm{DO}$, biological oxygen demand $\left(\mathrm{BOD}_{5}\right)$, total nitrogen $(\mathrm{TN})$, total coliforms and E.coli at all column depths. Experiments E, F, G, H, I and J were analyzed for dissolved nitrate ions $\left(\mathrm{NO}_{3}{ }^{-}\right)$at all column depths. Secondary effluent was introduced into the system for a consecutive period of 4 weeks to allow for biofilm formation before the start of the experiments.

\subsection{ANALYTICAL TECHNIQUES FOR WATER CONSTITUENTS}

Dissolved nitrate $\left(\mathrm{NO}_{3}{ }^{-}\right)$, sulphate $\left(\mathrm{SO}_{4}{ }^{2-}\right)$ and phosphate $\left(\mathrm{PO}_{4}{ }^{3-}\right)$ ions were measured using High Performance Liquid Chromatography (HPLC) with a Conductivity Detector (detection limits of 50, 75 and 125 $\mu \mathrm{g} / \mathrm{L}$ respectively). Ammonia nitrogen and TN were measured by the salicylate method (detention limit: 0.4 $\mathrm{mg} / \mathrm{L}$ ) and persulfate digestion method (detention limit: $2 \mathrm{mg} / \mathrm{L} \mathrm{N}$ ) respectively. Total coliforms and $E$. coli were measured by Membrane Filtration Method (Sensitivity: 1 CFU/100 mL). DOC was measured using a SHIMADZU TOC analyzer for solids and liquids (range: $4 \mu \mathrm{g} / \mathrm{L}$ to $4,000 \mathrm{mg} / \mathrm{L}$ ). DO was measured at the time of sampling using a portable digital meter (range: $0.1-20 \mathrm{mg} / \mathrm{L}$ ) and $\mathrm{BOD}_{5}$ was measured following the standard method for the examination of water and wastewater (Method 10230).

Percentage removal efficiency by the soil column were calculated with the following formula: 


$$
\operatorname{Removal}_{i}(\%)=\left(1-\frac{\operatorname{Eff~Conc~}_{i}}{\operatorname{Inf} \operatorname{Conc}}\right) \times 100
$$

Where Removal i is the percentage removal efficiency at sampling port $\mathrm{i}, \operatorname{Inf}$ Conc is the concentration at $0 \mathrm{~cm}$ sampling port, and Eff Conc ${ }_{i}$ is the effluent concentration at sampling port i. Sampling ports were placed at $0,10,30,50,70$ and $90 \mathrm{~cm}$ depth. Majority of concentrations were measure as mg/L except E.coli and total coliforms, which were measured as colony forming units by $100 \mathrm{ml}$ of sample (CFU/100).

\section{RESULTS AND DISCUSSION}

\subsection{DO CONSUMPTION}

DO in the wastewater was measured every day during the wetting cycle at inflow and outflow $(90 \mathrm{~cm})$ as an indicator of biofilm growth and stabilization. On the last day of the wetting cycle it was measured at all sampling ports. Average inflow DO was measured as $8.0 \mathrm{mg} / \mathrm{L}(\mathrm{SD}=0.4)$ and $5.9 \mathrm{mg} / \mathrm{L}(\mathrm{SD}=0.7)$ in the secondary effluents and simulated CSOs respectively. Average DO consumption on the last day of the wetting cycle at the $90 \mathrm{~cm}$ depth was $63 \%, 72 \%, 78 \%$ and $52 \%$ for experiments A (HRT= 1.4 hours) , B (HRT=2.8 hours), C (HRT= 13.1 hours) and D (HRT $=2.8$ hours) respectively. Results are shown in Figures 4 and 5.

Results show that oxygen consumption during the wetting cycle is proportional to the hydraulic retention time. Additionally, after approximately 3 days of operation, DO consumption does not change significantly for the remaining of the wetting cycle. This suggests that the biofilm reaches a quasi- steady state after a few days of column operation. It is also observed that the largest DO reduction occurs during the first $30 \mathrm{~cm}$ of the soil column for all experiments. This is attributed to higher biological activity of heterotrophic bacteria in the aerobic zone of the column. Oxygen for organic matter biodegradation is provided by the secondary effluents and also by air in the pore spaces in the soil. These results are also consistent with previous soil aquifer treatment studies that show the important role of the first few $\mathrm{cm}$ of the soil in the treatment 
process (Essandoh et al. 2013; Cha et al. 2005; Harun 2007). No clogging of the column was observed during the experiments conducted with secondary effluents. However, an average reduction of surface permeability by $31 \%$ was observed after 7 days of wetting the experiments with CSOs. This is expected due to the presence of particulate and colloidal organic matter in raw wastewater.

\subsection{ORGANIC MATTER}

Organic matter in secondary effluents from biological treatment is composed of natural organic matter, non-readily biodegradable organic carbon, soluble microbial products and synthetic organic compounds such as disinfection by-products (Fox et al. 2005). Biodegradable organic matter in the simulated CSOs is primarily composed of carbohydrates, proteins and grease (fats). SAT has shown to remove easily biodegradable carbon and synthetic organic compounds (Drewes and Fox 1999; Fox 2002). Average $\mathrm{DOC}$ and $\mathrm{BOD}_{5}$ in the secondary effluents of APCP were measured as $36.15 \mathrm{mg} / \mathrm{L}(\mathrm{SD}=2.99)$ and $3 \mathrm{mg} / \mathrm{L}(\mathrm{SD}=1)$ respectively. Furthermore, average $\mathrm{BOD}_{5}$ in the simulated CSO was measured as $19 \mathrm{mg} / \mathrm{L}(\mathrm{SD}=3)$.

Results show the majority of the DOC consumption from secondary effluents occurs during the first 50 $\mathrm{cm}$ of the column and reaches a maximum of $8 \%, 21 \%$ and $23 \%$ at the $90 \mathrm{~cm}$ depth for HRTs of $1.4,2.8$ and 13.1 hours respectively. Likewise, the majority of $\mathrm{BOD}_{5}$ removal occurs during the first $30 \mathrm{~cm}$ of the column in the experiment with CSOs and reaches a maximum of $54 \%$ at the $90 \mathrm{~cm}$ depth. Results are shown in figure 6.

Removal of DOC from secondary effluents showed dependency of both retention time and column depth up to approximately $50 \mathrm{~cm}$. Removal of DOC from secondary effluents was relatively low due to the soil type and HRTs. Previous SAT studies have also shown that DOC removal by fine to medium sands is low when compared with sandy loams and clay lenses that can achieve removals as high as $85 \%$ (Quanrud et al. 2003; Westerhoff and Pinney 2000). CSOs were only moderately improved in terms of readily available organic matter achieving an average $\mathrm{BOD}_{5}$ removal of $54 \%$. 
Mechanisms of organic carbon removal in SAT is a combination of biodegradation and absorption. However, the sustainability of SAT systems depends on biodegradation (Fox et al. 2005). Organic matter reduction shows that the SAT column operates under aerobic conditions at the three retention times, where DO is the elector acceptor. Positive correlations are observed between \% DO consumption and organic matter reduction for the first section of the curves (S1). These first section of the curves suggests organic matter removal is due to aerobic biodegradation with some adsorption. The second section of the curves (S2) where organic matter reduction increases but DO does not decrease significantly suggests removal due to adsorption and heterotrophic denitrification. The latter can be explained by the formation of anoxic or anaerobic zones in the column. This is consistent with the DO reduction results that show higher biologically activity in the first 30 to $50 \mathrm{~cm}$ of the column. See figure 7.

\subsection{E-COLI AND TOTAL COLIFORMS REDUCTION:}

Bacteria and viruses during SAT are removed by a variety of processes such as filtration, predation and adsorption. Removal efficiencies are affected by the retention time, grain size distribution, size of microbes, and the ability of microbes to persist in soil (Harun 2007). Geometric mean E.coli concentrations in the secondary effluent and CSOs were measured as $179 \mathrm{CFU} / 100 \mathrm{ml}$ and $750 \mathrm{CFU} / 100 \mathrm{ml}$, respectively. Additionally, Geometric mean total coliform concentrations in the secondary effluent and CSOs were measured as 1416 CFU/100 ml and $6750 \mathrm{CFU} / 100 \mathrm{ml}$, respectively. E.coli from the secondary effluents was not detected at the 90 $\mathrm{cm}$ depth at the three HRTs, with most of the removal occurring during the first $50 \mathrm{~cm}$ of the soil column. Therefore, it can be concluded that at least a log 3 removal is achieved at the $90 \mathrm{~cm}$ depth. Likewise, total coliforms were highly removed from the secondary effluents at the $90 \mathrm{~cm}$ depth, reaching average log reductions of 3, 1.7 and 2.1 for HRTs of $1.4,2.8$ and 13.1 hours respectively. Removals of E.coli and total coliforms from CSOs at the $90 \mathrm{~cm}$ depth were low, reaching average log reductions of 0.2 and 0.4 respectively at 
the $90 \mathrm{~cm}$ depth. Log reductions of E.coli and total coliforms are shown in figures 8 and 9. The Ontario Drinking Water Standards, Objectives and Guidelines specifies non detectable concentrations of E.coli and total coliforms in drinking water sources.

\subsection{NITROGEN REMOVAL}

Nitrogen removal was measured as nitrate $\left(\mathrm{NO}_{3}{ }^{-}\right)$and TN for the experiments with secondary effluents and CSOs respectively. The predominant form of nitrogen found in the secondary effluents from APCP is nitrate (APCP 2015). Nitrogen in simulated CSOs is present as ammonia and organic nitrogen. Nitrate removal is achieved by the reduction of nitrate to nitrogen gas through nitrite, nitric and nitrous oxide intermediaries by heterotrophic bacteria. Ammonia is consumed by a combination volatilization and adsorption with subsequent nitrification, which would yield high concentrations of nitrate in the effluent (Essandoh et al. 2013). Average nitrate concentration in inflow secondary effluents was measured as $18.37 \mathrm{mg} / \mathrm{L} \mathrm{NO}_{3}{ }^{-}-\mathrm{N}(\mathrm{SD}=4.04 \mathrm{mg} / \mathrm{L})$. Results show that nitrate removal from secondary effluents by SAT was not achieved at HRTs of 1.4 and 2.8 hours. However, at a HRT of 13.1 hours, an average $15 \%$ reduction was achieved at the $90 \mathrm{~cm}$ depth. Although oxygen is not completely consumed in the column effluent, heterotrophic denitrification can be explained by the formation of anoxic or anaerobic zones in the soil due to the nature and complexity of porous media. Average $\mathrm{TN}$ in the simulated CSOs was measured as $23.2 \mathrm{mg} / \mathrm{L}$ (S.D.=1.2 $\mathrm{mg} / \mathrm{L}$ ) with an average removal of $43 \%$ at the 90 cm depth. Results are shown in figure 10.

There are not guideline values for ammonia concentrations in the Ontario Drinking Water Standards, Objectives and Guidelines (2003) due to the fact that it is naturally produced in the body and efficiently metabolized in healthy people (Health Canada 2014). Organic nitrogen and nitrate limits by the Ontario Drinking Water Standards, Objectives and Guidelines are $0.15 \mathrm{mg} / \mathrm{L}$ and $10 \mathrm{mg} / \mathrm{L}$ (measured as nitrogen) respectively. However, organic nitrogen recommendation is only an operational guideline. Nitrate in drinking 
water poses more serious health issues, such as Methaemoglobinaemia (blue baby syndrome) and effects on the thyroid gland function in bottle-fed infants (Health Canada 2014). Therefore, nitrogen species are one of the most common reasons that groundwaters do not meet drinking water standards (Fox 2001). Average nitrate concentrations in secondary effluents are above the limit of $10 \mathrm{mg} / \mathrm{L}$ set by the Ontario Drinking Water Standards, Objectives and Guidelines. Even after the $15 \%$ removal achieved in experiment C, the nitrate concentration is higher than the accepted limit.

Concentrations of orthophosphate and ammonia in the secondary effluent from the APCP were below detectable levels at all column depths for all retention times. Additionally, dissolved sulphate ions were measured as $41.87 \mathrm{mg} / \mathrm{L}(\mathrm{SD}=3.23)$ and $27.47 \mathrm{mg} / \mathrm{l}(\mathrm{SD}=1.24)$ in secondary effluents and simulated CSOs respectively. No reductions in sulphate ions were observed at any of the column depths for any of the experiments.

\subsection{ENHANCE NITRATE REMOVAL FROM SECONDARY EFFLUENTS}

Nitrate ions from secondary effluents were not removed at the experiments with HRTs of 1.4 and 2.8 hours and only slightly removed (15\%) at the experiment at a HRT of 13.9 hours. Results of the experiments with methanol addition show a nitrate reduction of $46 \%(1: 1), 63 \%(3: 1)$ and $100 \%(6: 1)$ at the $90 \mathrm{~cm}$ depth for experiments $\mathrm{E}, \mathrm{F}$ and $\mathrm{G}$ respectively. Results of the experiments with glucose addition show a nitrate reduction of $32 \%(1: 1), 59 \%(3: 1)$ and $89 \%(6: 1)$ at the $90 \mathrm{~cm}$ depth for experiments $\mathrm{H}, \mathrm{I}$ and J respectively. Results are shown in figure 11. Results show nitrate removal is significantly enhanced by the addition of readily available organic matter. Added readily available organic matter provides energy for the reduction of nitrate and also for the production of biomass. As a result, more organic matter is required than the calculated based on stoichiometry. The amount of new biomass generated and the portion used for denitrification are specific to 
each compound. These findings highlight the importance of protecting recharge wetlands in regions with high permeability soils since they can provide the additional organic matter needed for denitrification.

\section{CONCLUSIONS}

Experiments with secondary effluents showed that oxygen consumption during the wetting cycle is proportional to the hydraulic retention time and largest DO reduction occurs during the first $30 \mathrm{~cm}$ of the soil column. This is attributed to higher biological activity of heterotrophic bacteria in the aerobic zone of the column. These results show the important role of the first few $\mathrm{cm}$ of the soil in the treatment process. Removal of DOC was low, reaching a maximum of $23 \%$ at the longest retention time, and showed dependency on both retention time and column depth up to approximately $50 \mathrm{~cm}$. Low DOC removal is explained by the high hydraulic conductivity of the soils and the nature of organic carbon in secondary effluents, which is mainly composed of non-readily biodegradable carbon such as natural organic matter, soluble microbial products and emergent contaminants. E.coli was not detected at the $90 \mathrm{~cm}$ depth at all hydraulic retention times and most of the removal occurs during the first $50 \mathrm{~cm}$ of the soil column. At least a log 3 removal is achieved. Likewise, total coliforms were almost completed removed at the $90 \mathrm{~cm}$ depth at experiments $A(>\log 3), B(\log 1.7)$ and C (log 2.1). Nitrate removal was slightly achieved at the longest retention time of 13.9 hours with an average 15 $\%$ reduction the $90 \mathrm{~cm}$ depth. Although oxygen is not completed consumed in the column effluent, heterotrophic denitrification can be explained by the formation of anoxic or anaerobic zones in the soil due to the nature and complexity of porous media.

Experiments with simulated CSOs, showed the largest DO reduction occurs during the first $30 \mathrm{~cm}$ of the soil column, which is attributed to higher biological activity of heterotrophic bacteria in the aerobic zone of the column. Oxygen consumption rates also consistently decrease as the depth of the soil increases for all hydraulic retention times. Unlike the experiments with secondary effluent, an average reduction of surface permeability by $31 \%$ was observed after 7 days of wetting. The majority of BOD5 removal occurs during the first $30 \mathrm{~cm}$ of the 
column and reaches a maximum of $54 \%$ at the $90 \mathrm{~cm}$ depth. Mechanisms of organic matter from CSOs by SAT is a combination of biodegradation, filtration and adsorption processes. The high BOD5 removal in comparison with DO reduction, suggests that there is a large contribution of filtration and adsorption in the removal of particulate and dissolve organic matter in the CSOs. E.coli and total coliform reductions were low with maximum average log reductions of 0.2 and 0.4 respectively at the $90 \mathrm{~cm}$ depth. Total nitrogen removal from simulated CSOs was moderate (43\%) and mainly due to nitrification and adsorption.

Methanol and glucose addition showed that denitrification of secondary effluents greatly improves when readily available organic matter is provided. Nitrate reductions of $100 \%$ and $89 \%$ were achieved at a ratio of 6:1 for methanol and glucose respectively. This is consistent with previous studies and provides scientific support for the importance of protecting recharge wetlands for groundwater quality protection in southwestern Ontario since they can provide additional organic matter needed for denitrification.

In summary, high permeability soils of southwestern Ontario, have the ability to polish secondary effluents in terms of DOC, E. coli and total coliforms. However, issues with the persistence of nitrates affects its suitability for potable aquifer recharge. Therefore, polished secondary effluent from the APCP by SAT will be more suitable for non-potable groundwater recharge. Recharge of potable aquifers may also be a possibility if wastewater effluents are de-nitrified. Regarding the simulated CSOs, sustainable SAT for non-potable or potable aquifer recharge is not achievable due to low removal of biological contamination, potential for high nitrate concentrations in the effluent and the occurrence of column clogging. Even though the removal of E.coli and total coliforms from secondary effluents were very high, disinfection is still recommended for the inactivation of viruses and protozoa. There are also concerns with the long-term effects on human health from exposure to contaminants such as pharmaceuticals and personal care products. 


\section{ACKNOWLEDGEMENTS}

This research was supported by Training Program in Clean Technologies for Water Refining and Nutrient and Energy Recovery (TWNER) at the University of Western Ontario, funded by the Collaborative Research and Training Experience Program of the Natural Sciences and Engineering Research Council of Canada.

\section{REFERENCES}

Bouwer, H. 1978. Groundwater Hydrology. McGraw Hill Book Company, New York.

Bouwer, H. 2002. Artificial recharge of groundwater: hydrogeology and engineering. Hydrogeology Journal 10 (1) :121-142. doi: 10.1007/s10040-001-0182-4

Canada Mortgage and Housing Corporation (CMHC). 2005. Research Report: Water Reuse Standards and Verification Protocol. Canada Mortgage and Housing Corporation, Ottawa, ON.

Cha, W., Choi, H., Kim, J. and Cho, J. 2005. Water quality dependence on the depth of the vadose zone in SAT-simulated soil columns. Water Science and Technology: Water Supply Vol 5 No 1 pp 17-24, IWA Publishing. Chapman, L and Putnam, D. 1984. The physiography of southern Ontario. Ontario Ministry of Natural Resources, 3rd ed, Toronto, ON.

City of London. 2014. Environmental and engineering services. Wastewater treatment operations division. Available from https://www.london.ca/residents/Sewers-Flooding/SewageTreatment/Documents/SEWAGE-Mar14.pdf [Accessed 15 October 2015].

City of London. 2015. Annual Report 2014. Adelaide Wastewater Treatment Plant. Environmental and Engineering Services Department. Wastewater Treatment Operations. Available from https://www.london.ca/residents/Sewers-Flooding/Sewage-Treatment/Documents/ADELAIDE14-AODA.pdf [Accessed 2 June 2015]. 
Dillon, P., Pavelic, P., Toze, S., Rinck-Pfeifferb, S., Martinc, R., Knaptond, A. and Pidsleye, D. 2006. Role of aquifer storage in water reuse. Desalination 188 (2006): 123-134. doi: 10.1016/j.desal.2005.04.109.

Drewes, J.E. and Fox, P. 1999. Fate of natural organic matter (NOM) during groundwater recharge using reclaimed water. Water Science and Technology. 40(9):241-248. doi: 10.1016/S0273-1223(99)00662-9.

Essandoh, H. M. K, Tizaouib, C., Mohameda, M.H.A. 2013. Removal of dissolved organic carbon and nitrogen during simulated soil aquifer treatment. 47(11): 3559-3572. doi: 10.1016/j.watres.2013.04.013.

Essandoh, H.M.K, Tizaouib, C., Mohameda, M.H.A, Amy, G. and Brdjanovic, D. 2011. Soil aquifer treatment of artificial wastewater under saturated conditions. Water Research 45 (14): 4211-4226. doi: 10.1016/j.watres.2011.05.017.

Exall, C., Marsalek, J. and Schaefer, K. 2006. Water Reuse in Canada: Opportunities and Challenges. National Water Research Institute, Environment Canada. In P. Hlavinek et al (eds), Integrated Urban Water Resources Management, pages 253 - 262. Canadian Crown. Printed in Netherlands. doi: 10.1007/1-4020-46855_26.

Fernández-Nava, Y., Marañón, E., Soons, J. and Castrillón, L. 2010. Denitrification of high nitrate concentration wastewater using alternative carbon sources. Journal of Hazardous Materials, 173(1-3): 682-688. doi: 10.1016/j.jhazmat.2009.08.14.

Fox, P. 2001. Soil Aquifer Treatment for Sustainable Water Reuse. 2001. AWWA Research Foundation and American Water Works Association. Denver, CO. ISBN 1-58321-113-0.

Fox, P., Aboshanp, W., and Alsamadi, B. 2005. Analysis of Soils to Demonstrate Sustained Organic Carbon Removal During Soil Aquifer Treatment. Journal of Environmental Quality, 34 (1): 156-163.

Gandhi, R., Ray, A., Sharma, V and Nakhla, G. 2014. Treatment of Combined Sewer Overflows Using Ferrate (VI). Water Environment Research, 86 (11):2202-2211. doi: 10.2175/106143014X14062131178475. 
Government of Canada. 2011. Canadian Guidelines for Domestic Reclaimed Water for Use in Toilet and Urinal Flushing. Available from http://healthycanadians.gc.ca/ [accessed 16 August 2016]

Haddad, B., Rozin, P., Nemeroff, C. and Slovic, P. 2009. The psychology of water reclamation and reuse: Survey findings and research road map. $1^{\text {st }}$ edition. Water Reuse Foundation. Alexandria, VA.

Harun, C.M. 2007. Analysis of multiple contaminants during soil aquifer treatment. M.Sc thesis, UNESCO-IHE Institute for Water Education, Delft, the Netherlands.

Health Canada. 2014. Guidelines for Canadian Drinking Water Quality. Available from http://www.hcsc.gc.ca/ewh-semt/pubs/water-eau/sum_guide-res_recom/index-eng.php\#t2 [accessed 23 November 2015]

Ministry of Environment (MOE). 2013. Amended Environmental Compliance Approval Number 739796SPH7. Issue Date: April 17, $2013 . \quad$ Available from https://www.accessenvironment.ene.gov.on.ca/instruments/0206-96SH3W-14.pdf [accessed 20 November 2015].

National Research Council (NRC). 2012. Water Reuse: Potential for Expanding the Nation's Water Supply Through Reuse of Municipal Wastewater. National Academy of Sciences. The National Academies Press, Washington, D.C.

National Center for Sustainable Water Supply (NCSWS). 2001. Investigation on Soil-Aquifer Treatment for sustainable water reuse. Arizona State University. Available from http://www.eas.asu.edu/ civil/ncsws/NCSWS.html [accessed 16 January 2015]

Naik, S. and Setty, Y. 2012. Biological denitrification of wastewater-A Mini Review on Carbon Source. International Conference on Chemical, Environmental Science and Engineering (ICEEBS'2012), Pattaya, Thailand. Available from http://psrcentre.org/images/extraimages/28\%20712580.pdf [accessed 18 January 2015] 
Ontario Drinking Water Standards, Technical Support Document, Objectives and Guidelines. 2003. Revised June 2006. Available from https://dr6j45jk9xcmk.cloudfront.net/documents/1140/81-drinking-waterstandards-objectives-and.pdf [accessed 21 November 2015]

Ontario Geological Survey (OGS). 2010. Surficial geology of Southern Ontario; Ontario Geological Survey, Ministry of Northern Development and Mines. Miscellaneous Release--Data 128-REV. ISBN 0-7794-5298-4 (set); ISBN 0-7794-5299-2 (v.1); ISBN 0-7794-5300-X (v.2). Sudbury, ON.

Peng, Y., Ma, Y., \& Wang, S. 2007. Denitrification potential enhancement by addition of external carbon sources in a pre-denitrification process. Journal of Environmental Sciences, 19(3): 284 289. doi: 10.1016/S10010742(07)60046-1.

Quanrud, D. M., Arnold, R. G., Lansey, K. E., Begay, C., Ela, W. and Gandolfi, A. J. 2003. Fate of effluent organic matter during soil aquifer treatment: biodegradability, chlorine reactivity and genotoxicity. Journal of Water and Health, 1(1): 33-45.

Region of Waterloo. 2010. Potable Groundwater Criteria Use in the Region of Waterloo. Available from http://www.regionofwaterloo.ca/en/abouttheenvironment/resources/wp_potable_water_policy.pdf [Access 20 December 2015)

Rodriguez, C., Van Buynder, P., Lugg, R., Blair, P., Devine, B., Cook, C. and Weinstein, P. 2009. Indirect Potable Reuse: A Sustainable Water Supply Alternative. International Journal of Environmental Research and Public Health, 6 (3): 1174-1209. doi: 10.3390/ijerph6031174

Sharma, S., Harun, C. and Amy, G. 2008. Framework for assessment of performance of soil aquifer treatment systems. Water Science \& Technology, 57 (6):941-946. doi: 10.2166/wst.2008.188

Wentworth, Chester K. 1922. A Scale of Grade and Class Terms for Clastic Sediments. The journal of geology, 30 (5): 377-392. doi: 10.1086/622910. 
Westerhoff, P., and Pinney, M. 2000. Dissolved organic carbon transformations during laboratory-scale ground water recharge using lagoon-treated wastewater. Waste Management, 20(1): 75-83. doi: 10.1016/S0956-053X(99)00277-9.

Wintgens, T., Salehi, F., Hochstrat, R. and Melin, T. 2008. Emerging contaminants and treatment options in water recycling for indirect potable use. Water Science \& Technology, 57 (1): 99-107. doi: 10.2166/wst.2008.799

Upper Thames River Conservation Authority (UTRCA). 2011. Upper Thames River Assessment Report: Municipal Drinking Water System Summary - City of London Water Supply System. Available from http://www.sourcewaterprotection.on.ca [access 21 May 2014]

US - Environmental Protection Agency (US-EPA). 2004. Guidelines for Water Reuse. Technology Transfer and Support Division, National Risk Management Research Laboratory. Available from https://nepis.epa.gov [accessed 1 August 2015]

US - Environmental Protection Agency (US-EPA). 2011. Keeping Raw Sewage \& Contaminated Stormwater Out of the Public's Water. Available from http://www.epa.gov/region02/water/sewer-report-32011.pdf [accessed 3 September 2015]

US - Environmental Protection Agency (EPA). 1970. Water Quality Office. Methanol requirement and temperature effects in wastewater denitrification. Available from http://www3.epa.gov/ [accessed 1 November 2015]. 


\section{TABLES}

1.

\begin{tabular}{cc|cccc}
\multicolumn{2}{c|}{$\begin{array}{c}\text { Major oxides } \\
\text { Wt\% }\end{array}$} & \multicolumn{4}{c}{ Trace elements } \\
ppm & \multicolumn{1}{c}{ ppm } \\
\hline \hline $\mathrm{SiO}_{2}$ & 60.10 & $\mathrm{Mo}$ & 2 & $\mathrm{Co}$ & 3 \\
$\mathrm{Al}_{2} \mathrm{O}_{3}$ & 7.23 & $\mathrm{Nb}$ & 5 & $\mathrm{Mn}$ & 348 \\
$\mathrm{Fe}_{2} \mathrm{O}_{3}$ & 1.80 & $\mathrm{Zr}$ & 87 & $\mathrm{Cr}$ & 61 \\
$\mathrm{~K}_{2} \mathrm{O}$ & 1.45 & $\mathrm{Y}$ & 17 & $\mathrm{~V}$ & 23 \\
$\mathrm{Na}_{2} \mathrm{O}$ & 1.95 & $\mathrm{Sr}$ & 265 & $\mathrm{Ba}$ & 365 \\
$\mathrm{MgO}$ & 2.51 & $\mathrm{U}$ & 3 & $\mathrm{Sc}$ & $<5$ \\
$\mathrm{CaO}$ & 12.70 & $\mathrm{Rb}$ & 66 & & \\
$\mathrm{TiO}_{2}$ & 0.26 & $\mathrm{Th}$ & 6 & & \\
$\mathrm{MnO}^{2}$ & 0.05 & $\mathrm{~Pb}$ & $<5$ & & \\
$\mathrm{P}_{2} \mathrm{O}_{5}$ & 0.08 & $\mathrm{As}$ & 9 & & \\
$\mathrm{Cr}_{2} \mathrm{O}_{3}$ & 0.02 & $\mathrm{Ga}$ & 7 & & \\
$\mathrm{BaO}$ & 0.05 & $\mathrm{Zn}$ & 26 & & \\
$\mathrm{SrO}_{\mathrm{L} O \mathrm{O} . \mathrm{I}}$ & 0.04 & $\mathrm{Cu}$ & 12 & & \\
\hline
\end{tabular}

Table 1. Major oxides and trace elements composition of the sieved MC sand

2.

\begin{tabular}{ccccc} 
Experiment & $\begin{array}{c}\text { Wet/Dry } \\
\text { cycles }\end{array}$ & Column influent & HRT & $\begin{array}{c}\text { Hydraulic } \\
\text { conductivity } \\
\text { K }\end{array}$ \\
(hours) & (m/d) \\
\hline A & 3 & Secondary Effluent & 1.4 & 5.3 \\
B & 3 & Secondary Effluent & 2.8 & 2.7 \\
C & 3 & Secondary Effluent & 13.9 & 0.5 \\
\hline D & 2 & Combined Sewer Overflows & 2.8 & 2.7 \\
\hline E & 2 & Secondary + methanol (1:1)* & 2.8 & 2.7 \\
F & 2 & Secondary + methanol (1:3)* & 2.8 & 2.7 \\
G & 2 & Secondary + methanol (1:6)* & 2.8 & 2.7 \\
\hline E & 2 & Secondary + glucose (1:1)* & 2.8 & 2.7 \\
F & 2 & Secondary + glucose (1:3)* & 2.8 & 2.7 \\
G & 2 & Secondary + glucose (1:6)* & 2.8 & 2.7 \\
\hline & & *Nitrogen to carbon ratio &
\end{tabular}


Table 2. Summary of experiments 


\section{FIGURES CAPTIONS}

Figure 1. Surficial permeability southwestern Ontario.

Figure 2. Primary material composition of high permeability soils of southwestern Ontario.

Figure 3 Schematic representation of the experimental set up

Figure 4. Average daily DO consumption (\%) - 7 days wetting cycle $\left(H R T_{A}=1.4 h, H R T_{B}=2.8 \mathrm{~h}, H R T_{C}=13.9 h, H R T_{D}=\right.$ $2.8 \mathrm{~h}$ )

Figure 5. Average percentage DO reduction by column depth $\left(H R T_{A}=1.4 \mathrm{~h}, H R T_{B}=2.8 \mathrm{~h}, H R T_{C}=13.9 \mathrm{~h}, H R T_{D}=2.8\right.$ h)

Figure 6. Percentage organic matter reduction by column depth $\left(\mathrm{HRT}_{\mathrm{A}}=1.4 \mathrm{~h}, \mathrm{HRT}_{\mathrm{B}}=2.8 \mathrm{~h}, \mathrm{HRT}_{\mathrm{C}}=13.9 \mathrm{~h}, \mathrm{HRT}_{\mathrm{D}}=\right.$ $2.8 \mathrm{~h})$

Figure 7. Average \% organic matter reduction vs average \% DO consumption $\left(H R T_{A}=1.4 h, H R T_{B}=2.8 h, H R T_{C}=13.9\right.$ h, $\left.\mathrm{HRT}_{\mathrm{D}}=2.8 \mathrm{~h}\right)$

Figure 8. Average percentage E.coli reduction by column depth $\left(H R T_{A}=1.4 \mathrm{~h}, H R T_{B}=2.8 \mathrm{~h}, H R T_{C}=13.9 \mathrm{~h}, H R T_{D}=\right.$ $2.8 \mathrm{~h})$

Figure 9. Average percentage total coliforms reduction by column depth $\left(H R T_{A}=1.4 \mathrm{~h}, H R T_{B}=2.8 \mathrm{~h}, H R T_{C}=13.9 \mathrm{~h}\right.$, $\left.\mathrm{HRT}_{\mathrm{D}}=2.8 \mathrm{~h}\right)$

Figure 10. Average percentage nitrogen (nitrates or TN) reduction by column depth $\left(H R T_{C}=13.9 h, H_{R} T_{D}=2.8 \mathrm{~h}\right.$ )

Figure 11. Percentage nitrate reduction from secondary effluents by column depth (HRT $=2.8 \mathrm{~h}$ ) 


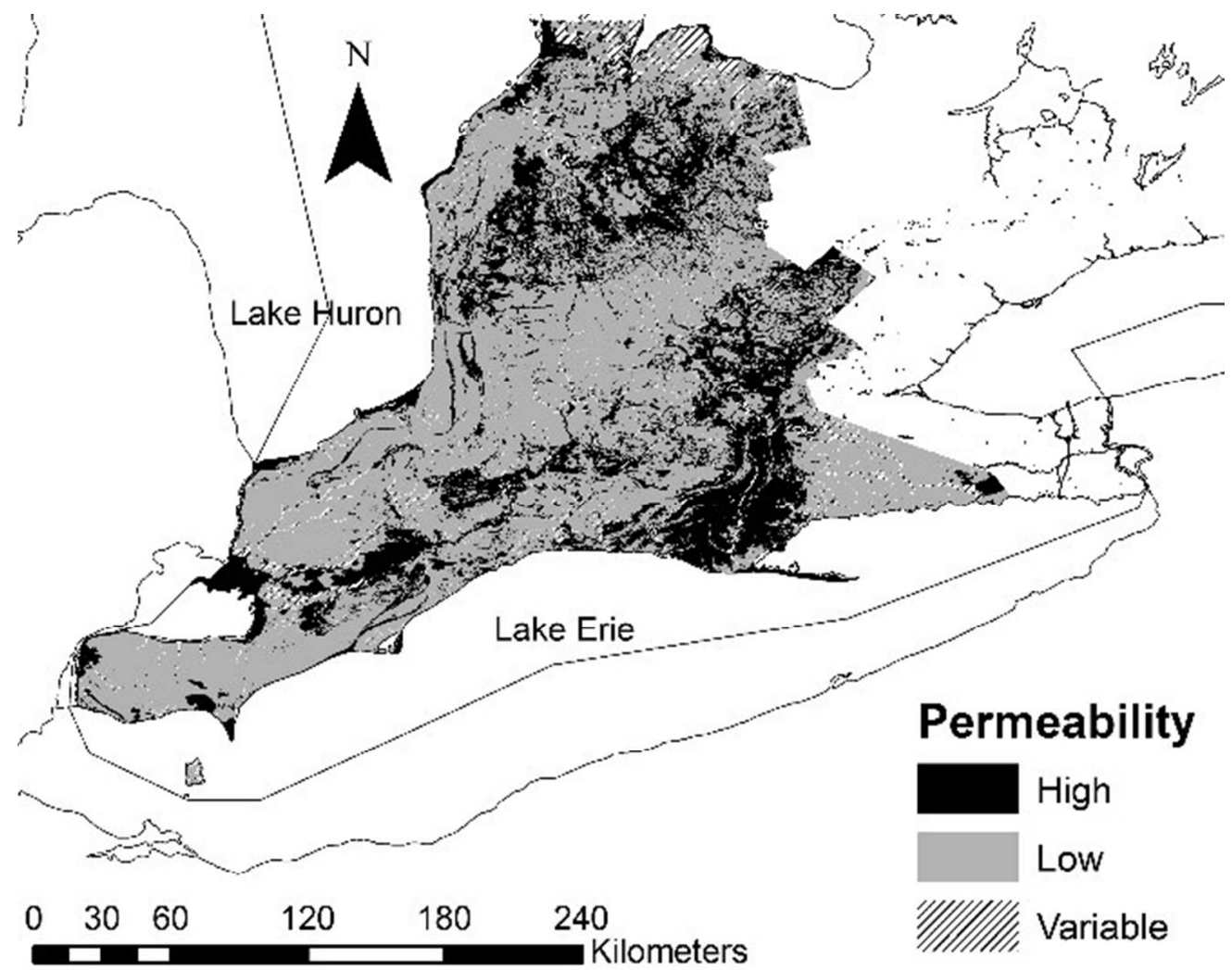

$76 \times 62 \mathrm{~mm}(220 \times 220 \mathrm{DPI})$ 


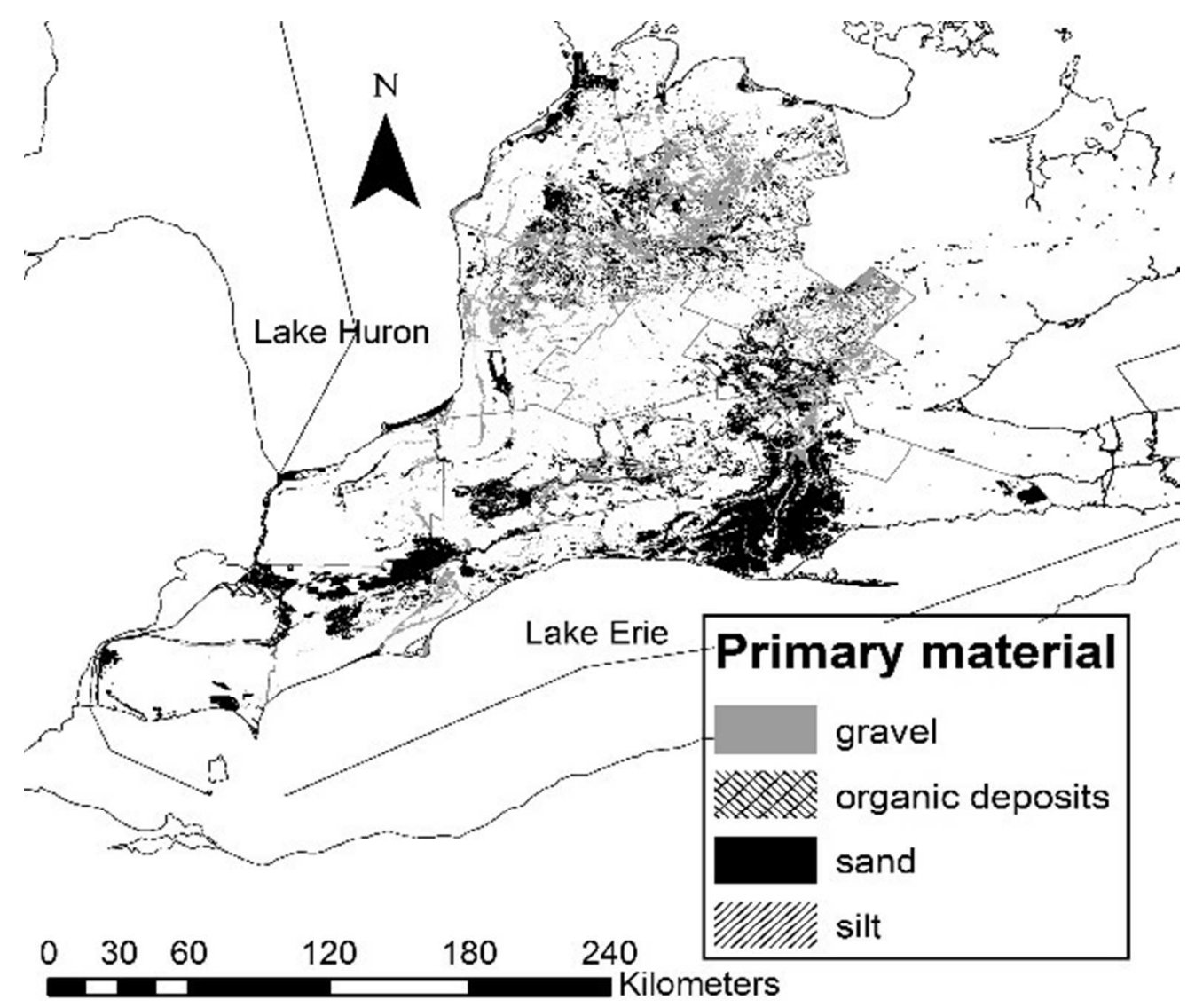

$74 \times 65 \mathrm{~mm}(220 \times 220$ DPI $)$ 


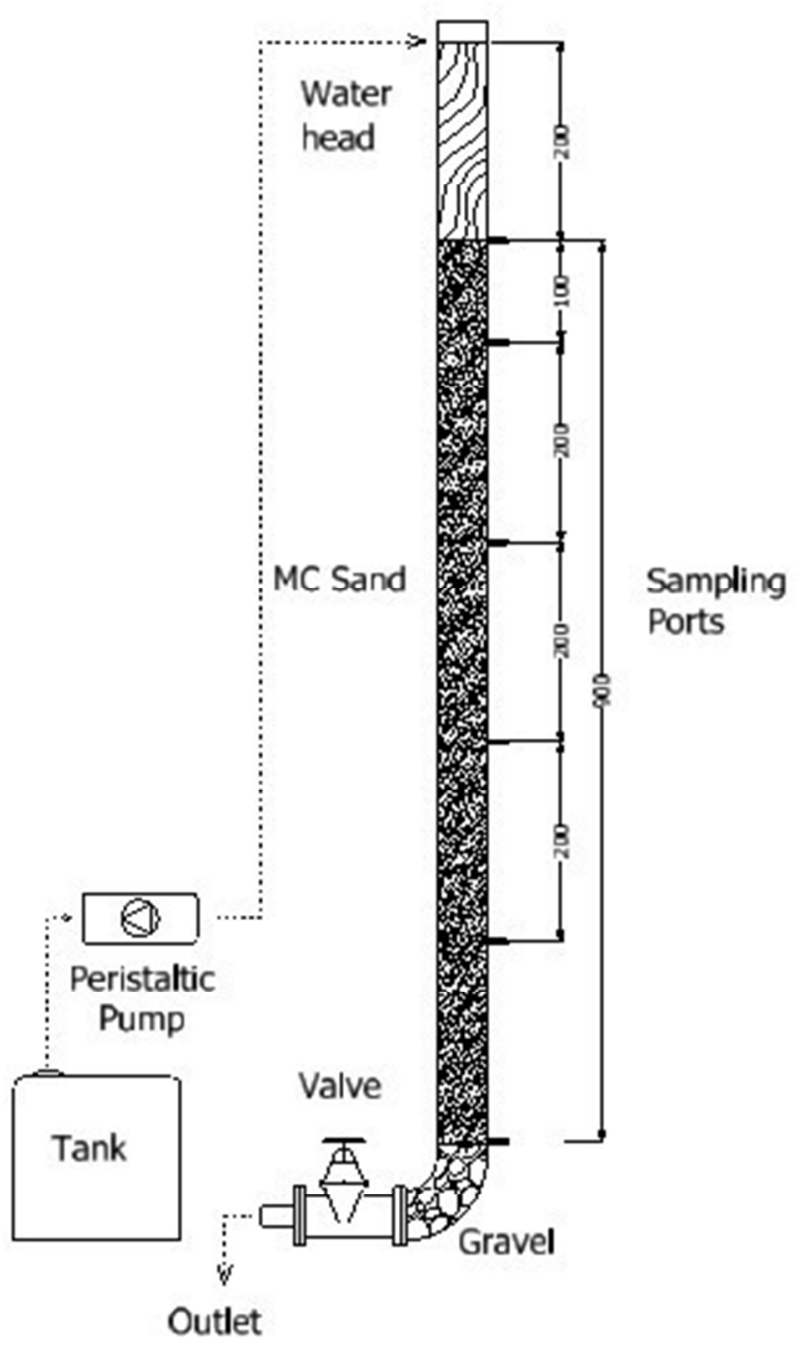

$88 \times 143 \mathrm{~mm}(96 \times 96$ DPI) 


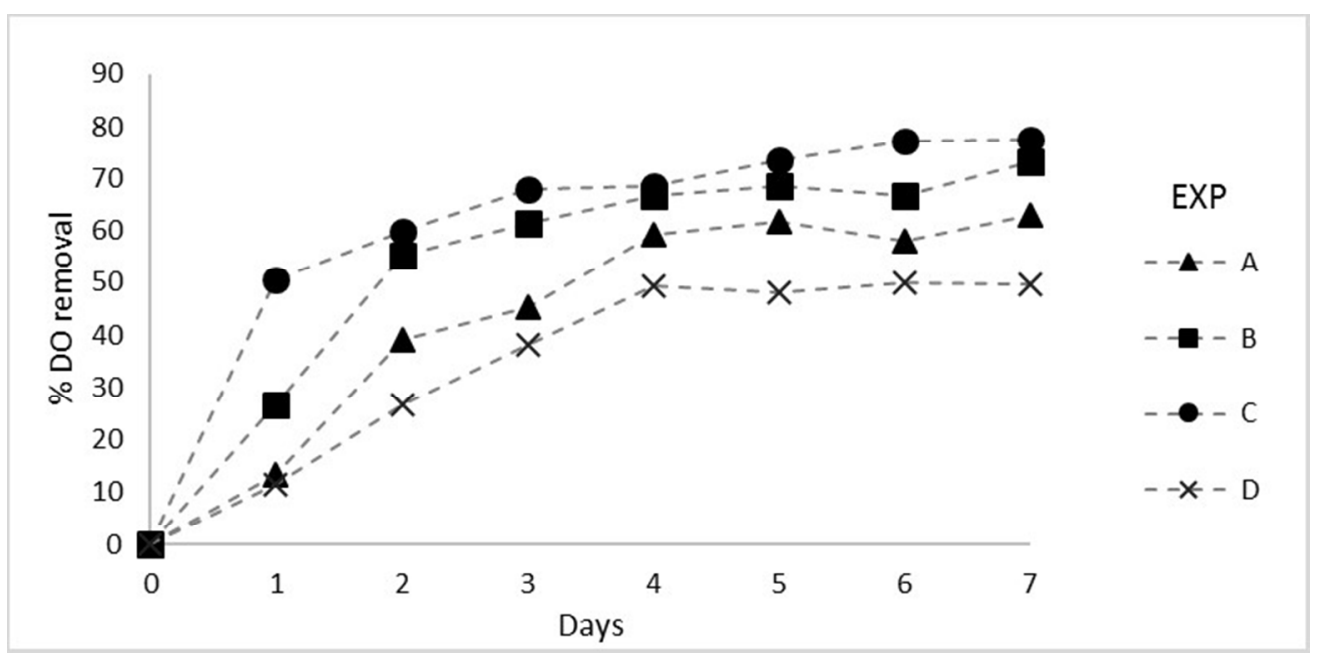

$135 \times 66 \mathrm{~mm}(150 \times 150 \mathrm{DPI})$ 


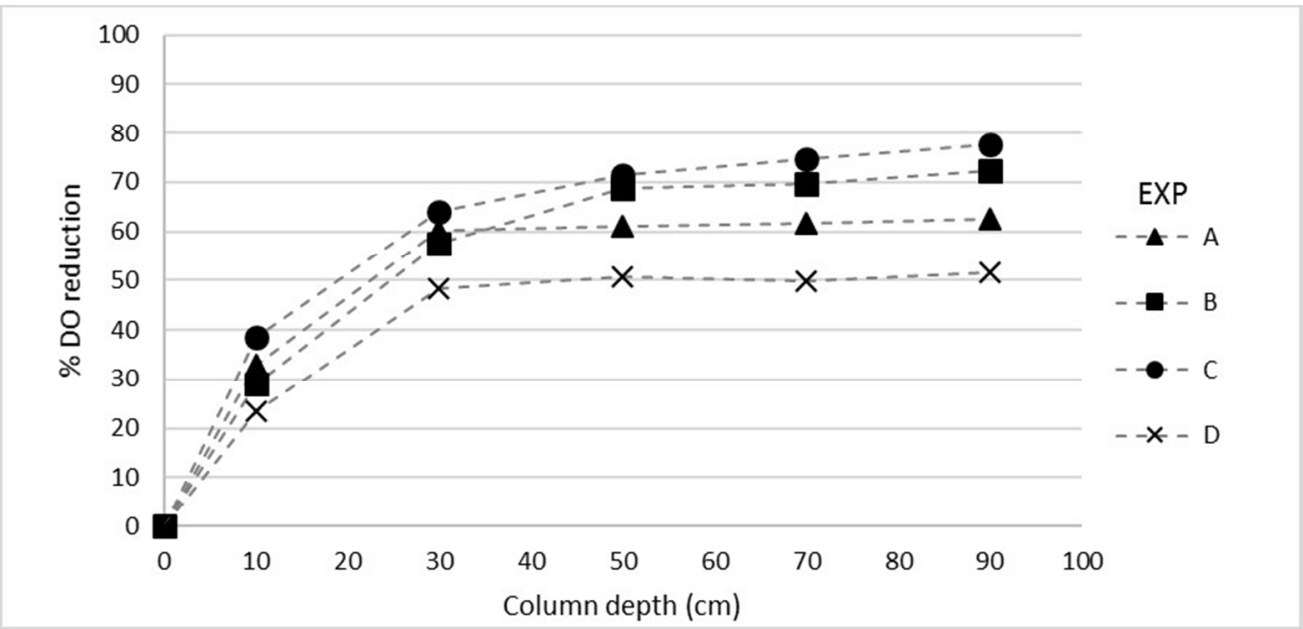

$151 \times 72 \mathrm{~mm}(150 \times 150 \mathrm{DPI})$ 


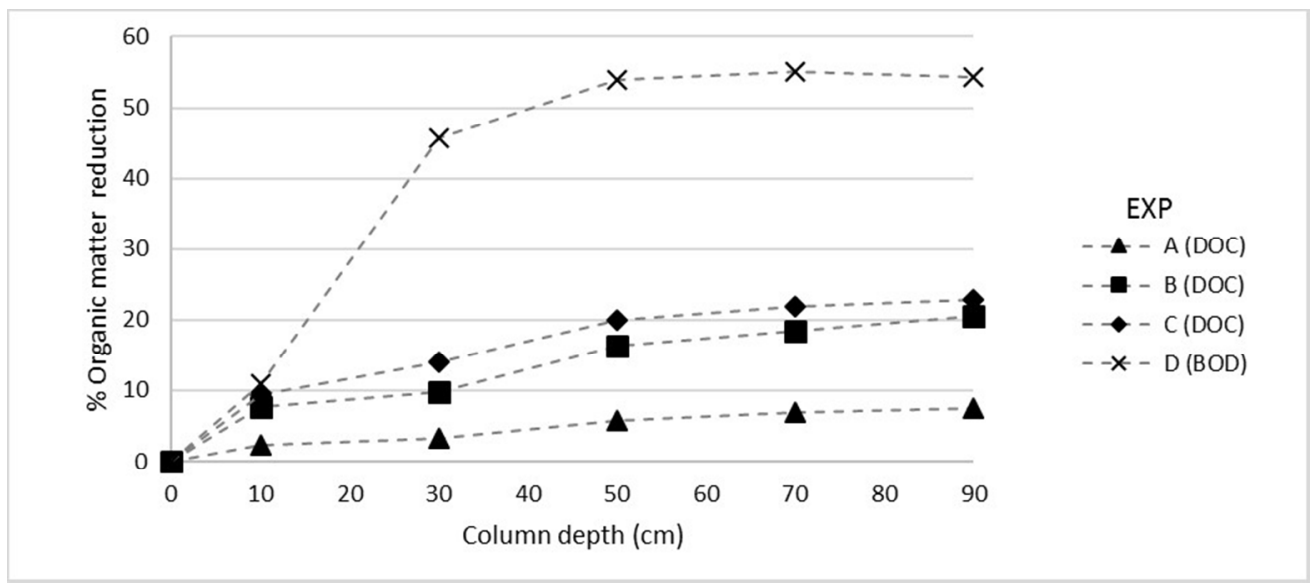

$162 \times 71 \mathrm{~mm}(150 \times 150 \mathrm{DPI})$ 


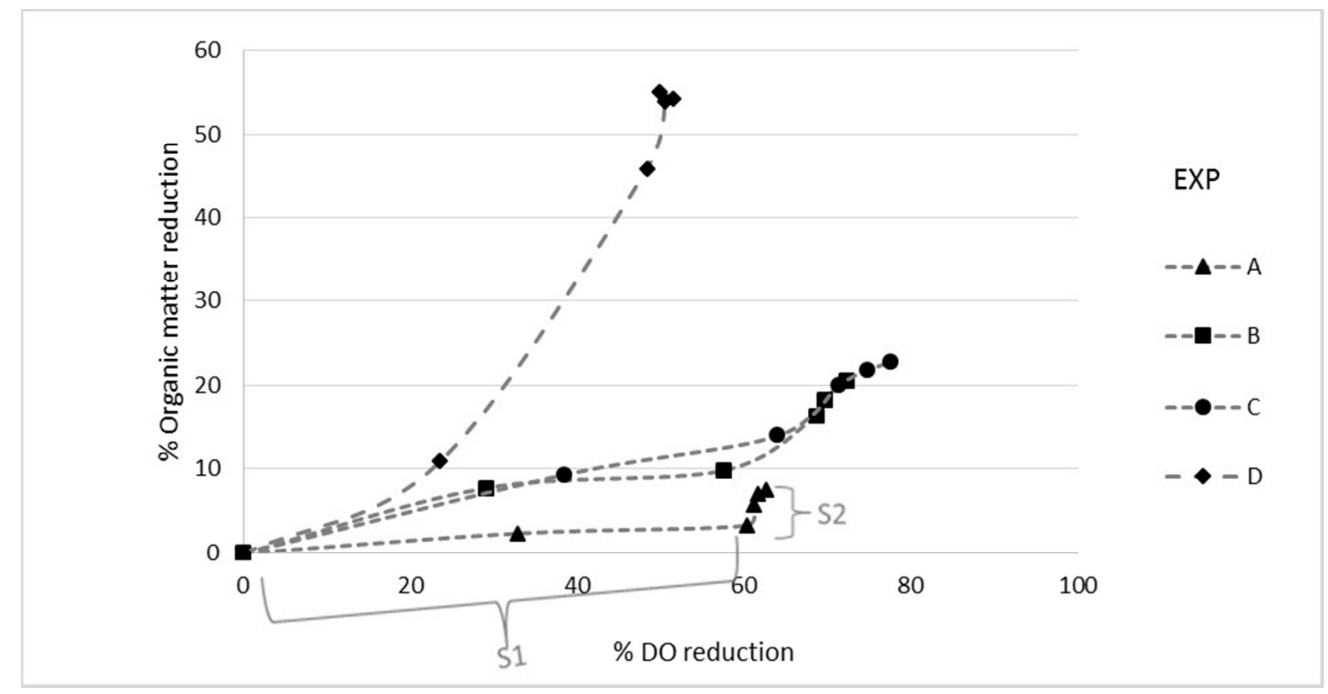

$161 \times 84 \mathrm{~mm}(150 \times 150 \mathrm{DPI})$ 


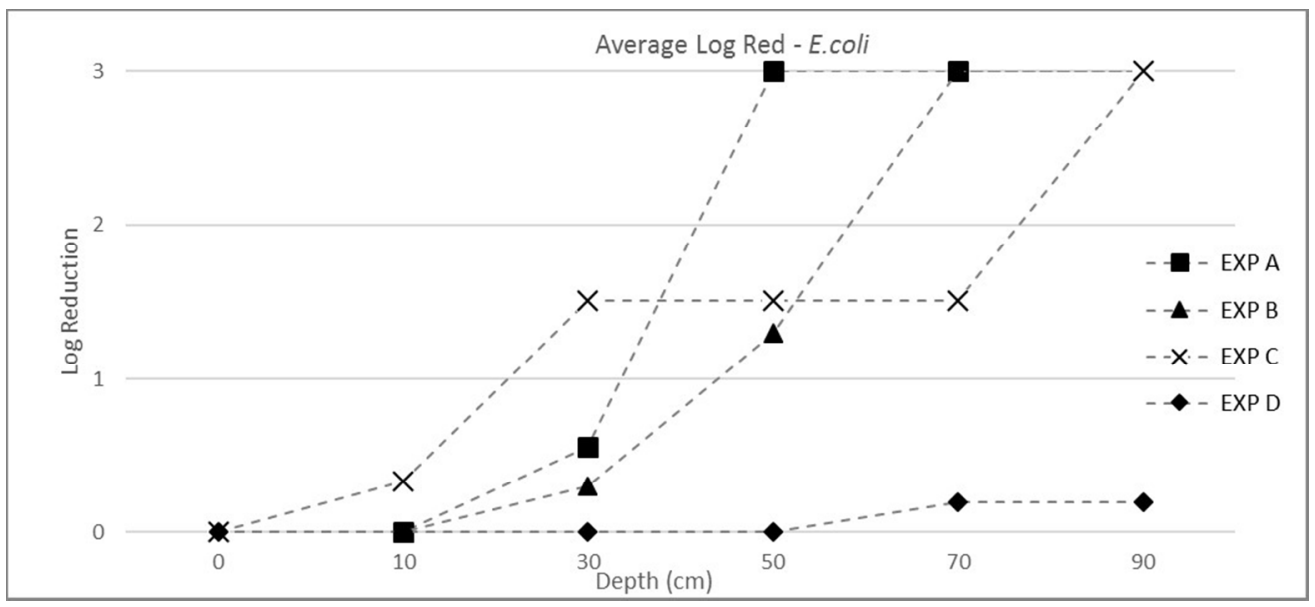

$178 \times 80 \mathrm{~mm}(150 \times 150 \mathrm{DPI})$ 


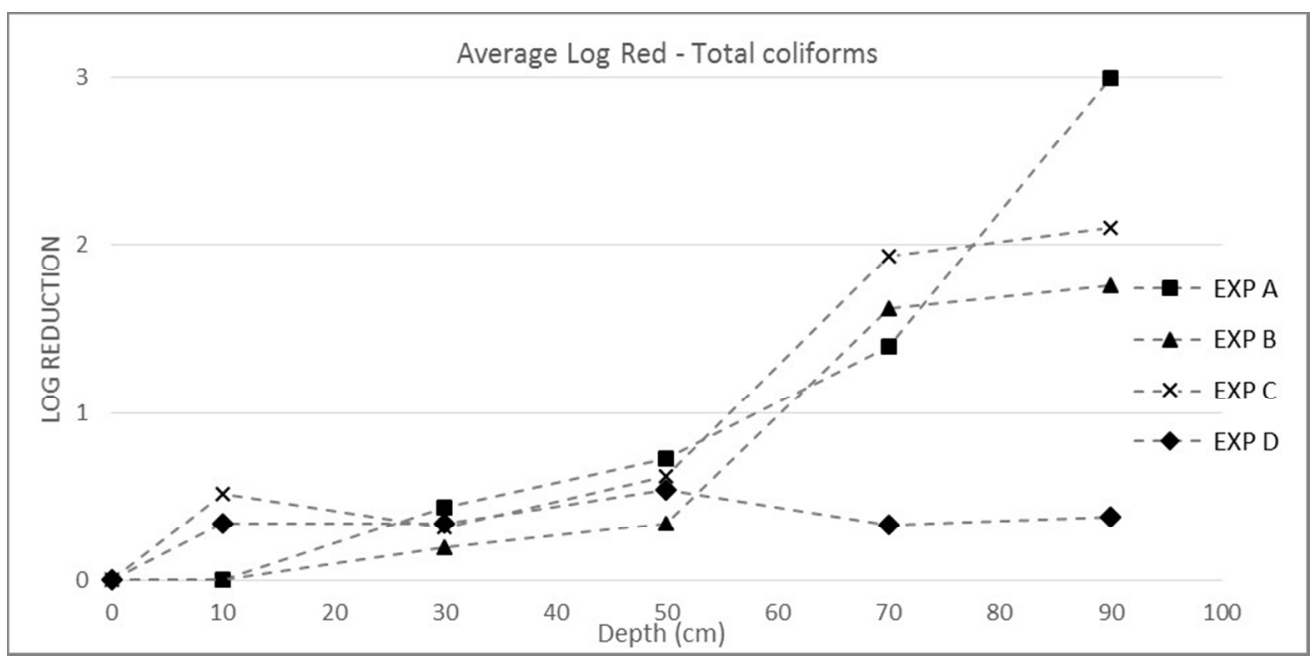

$163 \times 80 \mathrm{~mm}(150 \times 150 \mathrm{DPI})$ 


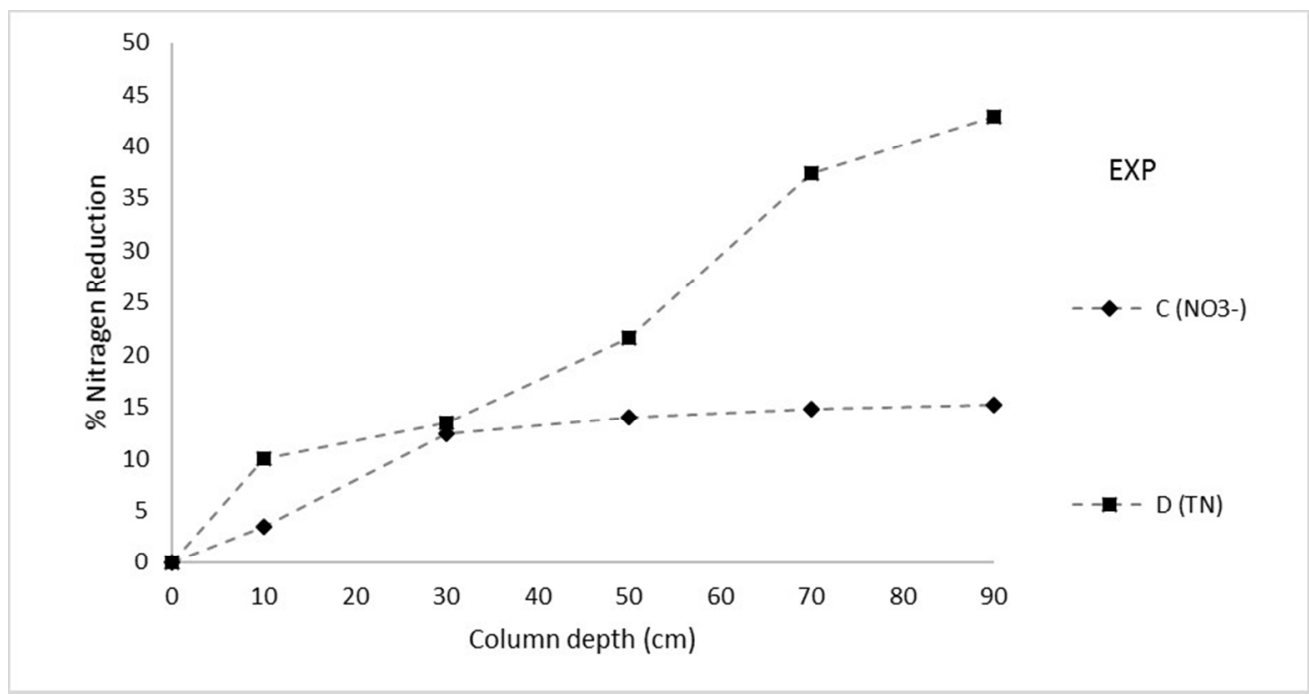

$158 \times 83 \mathrm{~mm}(150 \times 150 \mathrm{DPI})$ 


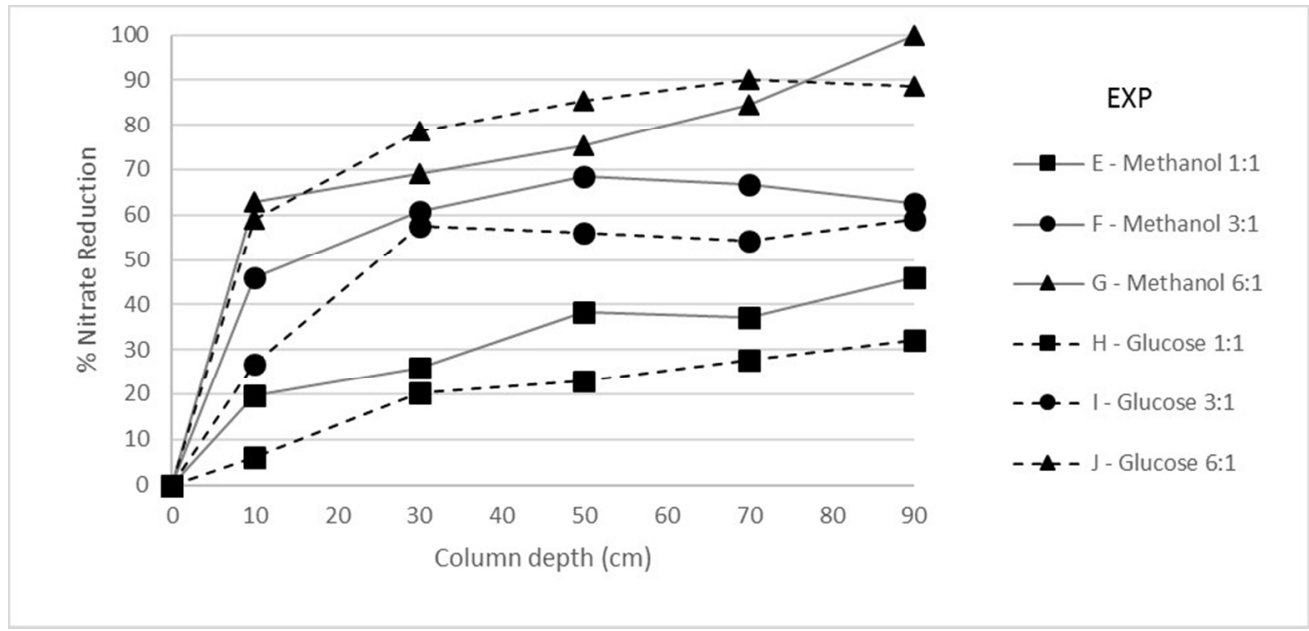

$165 \times 79 \mathrm{~mm}(150 \times 150 \mathrm{DPI})$ 